\title{
Varietal Characterization and Quality Assessment of Mango Hybrid and their Parents through Morphological and Biochemical Markers
}

\author{
Syed Razaul Islam, Kumari Karuna*, Abha Kumari, Abhay Mankar and Feza Ahmad
}

Department of Horticulture (Fruit \& Fruit Technology), Bihar Agricultural University, Sabour, Bhagalpur-813210, Bihar, India

*Corresponding author

\begin{tabular}{|c|c|}
\hline & A B S T R A C T \\
\hline $\begin{array}{l}\text { Varietal } \\
\text { identification, } \\
\text { Description, } \\
\text { Improvement, } \\
\text { Morphology, } \\
\text { Biochemical }\end{array}$ & \multirow{3}{*}{$\begin{array}{l}\text { Although, India is the largest mango producing country in the world and also is the home } \\
\text { of more than } 1,000 \text { mango cultivars but the productivity of mango in our country is low. } \\
\text { Hence improvement work for the development of mango cultivars with higher yield and } \\
\text { productivity is the utmost importance. For successful improvement work, proper } \\
\text { identification of genetic resources or the parental materials is the basic need. Hence, the } \\
\text { aim of study was to identify, characterize and recommend mango cultivars to broaden the } \\
\text { varietal spectrum. The selected samples were described for various characteristics of tree } \\
\text { growth (tree height, shape, foliage colour and density), leaf (leaf length, leaf width, leaf } \\
\text { area and leaf shape), fruit (length, width, weight, colour and their attractiveness) and bio- } \\
\text { chemical attributes (total soluble solids, titrable acidity, TSS/acidity ratio, chlorophyll } \\
\text { content \& beta-carotene). Of the } 8 \text { hybrids with their parentage, only three hybrids (Hybrid } \\
60-1 \text {, Alfazli and Prabhashankar) and one parentage Fazli showed distinctive fruit } \\
\text { characters and market potential. The studies helped to develop suitable morphological and } \\
\text { biochemical markers for improvement of mango germplasm to establish suitable varieties } \\
\text { for domestic and export markets. }\end{array}$} \\
\hline Article Info & \\
\hline $\begin{array}{l}\text { Accepted: } \\
\text { 07 March } 2019 \\
\text { Available Online: } \\
10 \text { April } 2019\end{array}$ & \\
\hline
\end{tabular}

\section{Introduction}

Mango (Mangifera indica L) is the most popular fruit crop in India. It occupies relatively same position as that enjoyed by apple in temperate America or Europe. Due to its popularity and importance, it is 'known as king' of fruits belongs to family Anacardiaceae, order Sapindales (Jha et al., 2010). It is believed to have originated in Indo-Burma region (Popenoe, 1927; Mukherjee, 1951; De Candolle, 1904). India is leading at the top with mango production of
18.24 million tons with $42.2 \%$ of world's total mango production (NHB, 2014). Production of mango in Bihar is 13 lakh tons which constitutes around $34 \%$ of the total fruit production of the state with productivity of 9.2 MT/ha (NHB, 2014).

Consumption of tropical and sub tropical this fruits have increased significantly in the world due to their nutritional and bioactive properties (Poovarodom et al., 2010) but the production of quality mango is not increasing at a level, required to compete in the 
international market. One of the most important causes of above problem is the lack of genetic diversity in addition to pests and diseases. Hence, Improvement in plant material can be done by adopting hybridization, genetic mutation, selection of chance seedlings, chromosome doubling etc., with in species or varieties (Mian and Nasir, 1989). However, in mango breeding, hand pollination is surprisingly unrewarding, as success rate of three fruits per 1000 pollinations have been recorded (Mukherjee et al., 1968). Therefore, only three present commercial cultivars in India have evolved from controlled breeding like Mallika, Amrapalli, Ratna (Chadha and Pal, 2004).

One should recognize that all the germplasm available is useful one way or other (Knight, 1993). If it is lacking marketable value, then it may be suitable for some other purposes, like disease resistance, climatic adaptation, home gardening etc. (Campbell, 1995). Therefore, germplasm is a source of variation for new assortment and the time has come to conserve these precious genetic resources and to improve the yield and range of available varieties through collection of local indigenous germplasm. For germplasm collection, varietal characterization is an important component of mango improvement and breeding. It lays the foundation for further scientific progress in developing new cultivars. Since morphological and biochemical characterization of mango germplasm is difficult and lacks expertise, it has never been addressed properly, though mango remains the second most important fruit crop of India.

The objectives of the study were to identify, characterize and recommend mango germplasm to broaden the varietal spectrum and increasing the mango harvesting window, by selecting late maturing germplasm with good fruit characteristics. Another goal was to select key morphological and biochemical markers in mango as future guidelines for varietal identification and breeding work.

\section{Materials and Methods}

The present investigations were carried out in the Horticultural garden of Department of Horticulture (Fruit and Fruit Technology), Bihar Agricultural University, SabourBhagalpur during 2015-16. This particular district is the hot spot for mango genotype and hybrid production. Eight hybrids and eight genotypes of mango evaluated in the present study (Table 1 and Fig. 1). Accessions were characterized based on mango descriptors listed (IPGRI, 2006).

\section{Morphological parameters}

\section{Tree growth descriptors}

Data concerning to tree and growth description was tree height, foliage density, foliage colour and tree shape. Tree Height was measured from ground level to tip of the highest shoot. If the Plant height is less than 6 $\mathrm{m}, 6.1-9.0 \mathrm{~m}, 9.1-12.0 \mathrm{~m}$, greater than 12 meter is considered as short, medium, tall and very tall respectively. The foliage density, foliage colour and tree shape was recorded during the month of December according to NBPGR descriptor of mango.

\section{Leaf descriptors}

The observation on leaf length, leaf width, leaf area and shape was recorded from fully expanded leaves. Leaf length was measured from apex to base of lamina, leaf width from the broad area of leaf lamina and leaf area by using portable leaf area meter of three leaves from each treatment and the average were calculated. Leaf shape was recorded as per the descriptor of NBPGR. 


\section{Fruit descriptors}

The fruits were harvested at full maturity. Five fruits were selected randomly from each cultivar of all replications and their ultimate lengths and width were recorded with the help of slide calipers in $\mathrm{mm}$ and weighted carefully with the help of electronic balance and average of each observation was worked out.

\section{Biochemical parameters}

\section{Fruit quality}

The total soluble solids (TSS) of the mango juice obtained from all the mango hybrids and their parentage studied were estimated in Brix at harvest using a digital refractometer (Atago, Tokyo, Japan).

The total titrable acidity component was measured by the Titration method (AOAC, 2000) as described previously by (Kumari et al., 2015). TSS/Acidity of the fruit was calculated by dividing the average value of TSS to that of the acidity.

\section{Leaf quality}

The chlorophyll content (chlorophyll a and b) of the leaves were analyzed by using the method of Barnes et al., (1992) and beta carotene content was estimated by $\mathrm{S}$. Ranganna (2011).

\section{Results and Discussion}

\section{Morphological parameters}

Data concerning to growth descriptors like tree height, tree shape, foliage color and foliage density, leaf descriptor like leaf shape, fruit descriptor like fruit colour and their attractiveness of mango hybrids and their parents were presented in Table 2.
The data regarding to leaf descriptor like leaves length, width, area was recorded under different hybrids and genotype given in Table 3. A critical examination of the data shows that there was significant variation for leaf length, leaf area whereas non significant variation for leaf width. The maximum leaf length $(29.26 \mathrm{~cm})$ and area $\left(145.36 \mathrm{~cm}^{2}\right)$ was recorded in the hybrid Alfazli and width $(8.73 \mathrm{~cm})$ was in Fazli and lowest leaf length, width and area was found in Gulabkhas $(16.43 \mathrm{~cm}), \quad(8.73 \mathrm{~cm})$ and $\left(50.63 \mathrm{~cm}^{2}\right)$ respectively. The current study showed considerable variations in leaf morphological characters among the eight hybrids and their parentage (Tables 2 and 3). Variations in leaf characteristics are reported to be due to genetic divergence of mango cultivars (Shivashankara and Mathai, 2000; Sharma et al., 1999, Reddy et al., 2000 and Rymbai et al., 2014) and environmental effect.

The data with respect to fruit weight, length and width under different hybrids and genotype were also given in Table 3. A careful scrutiny of the data indicates that there was a significant variation in fruit weight, length and width among different hybrids and their parentage. The highest fruit weight $(490.66 \mathrm{~g})$, fruit length $(136.44 \mathrm{~mm})$ and fruit width $(88.57 \mathrm{~mm})$ was produced by Fazli.

The minimum fruit weight $(135.55 \mathrm{~g})$, fruit length $(77.32 \mathrm{~mm})$ and fruit width $(56.65$ $\mathrm{mm}$ ) was noted in hybrid Sabri. We suggest that the use of only fruit traits can give a good perspective about mango diversity. Mango for commercial exploitation should exhibit low fibre content in fruits with short fibres; high length, width, thickness and weight of fruits; and high contents of pulp (Human and Rheeder, 2004). (Lodh et al., 1974) and (Iqbal et al., 1995) also reported the variation of fruit weight among the different mango varieties. This variation may be due to genetic or physiological factors. A wide range of 
variation was observed among the germplasm in respect of fruit length and breadth.

\section{Biochemical parameters}

The data concern to total soluble solids (TSS) content, titrable acidity and TSS acidity ratio in mango juice fruit for different hybrids and genotype of mango were provided in Table 4. The scrutiny of data clearly indicates that the variants differed significantly with respect to TSS content, titrable acidity and TSS/Acidity in fruits and chlorophyll $a$ and $b$ and beta carotene in leaf. The maximum TSS content (22.6 ${ }^{\mathrm{O}}$ Brix) and TSS/Acidity (173.1) was recorded in Amrapali whereas highest acidity was found in Prabhashankar (0.39 \%). Minimum value for TSS, titrable acidity, TSS/Acidity was obtained in Fazli (17.0 ${ }^{\mathrm{O}}$ Brix), Gulabkhas $(0.13 \%)$, Prabhashankar (56.92) respectively. The TSS of fruit juice gives a rough idea of the sweetness because TSS includes all type of soluble solids. The improvement in TSS content of fruits may be due to the increased hydrolysis of polysaccharides into sugars and also due to enhanced mobilization of carbohydrates from organic acids.

The results of the present investigation showed close conformity with the findings of Kumar and Singh (2005) and Sengupta et al., (2006). Acidity of the fruits gives a blend, acidity and flavour provide quality to the fruits. The acidity of the fruit is directly related to ripening of the fruit though it is a genetical character of the individual variety. Acidity decreased with the maturity and ripening of fruits. Kumar et al., (1992) suggested that this might be due to the conversion of acids into salts and sugars by enzymes particularly invertage.

Table.1 Details of 8 hybrids Mango (Mangifera indica L.) with their parentage

\begin{tabular}{|c|l|l|l|}
\hline Treatments & $\begin{array}{l}\text { Name of Hybrids/ } \\
\text { parents }\end{array}$ & Parentage & Year \\
\hline $\mathbf{H}_{\mathbf{1}}$ & Mahmood bahar & Bombai X Kalapadi & 1951 \\
\hline $\mathbf{H}_{\mathbf{2}}$ & Prabhashankar & Bombai X Kalapadi & 1951 \\
\hline $\mathbf{H}_{\mathbf{3}}$ & Alfazli & Alphonso X Fazli & 1980 \\
\hline $\mathbf{H}_{\mathbf{4}}$ & Sabri & Gulabkhas X Bombai & 1989 \\
\hline $\mathbf{H}_{\mathbf{5}}$ & Jawahar & Gulabkhas X Mahmood bahar & 1980 \\
\hline $\mathbf{H}_{\mathbf{6}}$ & Sunderlangra & Langra X Sunderprasad & 1980 \\
\hline $\mathbf{H}_{\mathbf{7}}$ & Hybrid 140 & Langra X Amrapalli & - \\
\hline $\mathbf{H}_{\mathbf{8}}$ & Hybrid 60 -1 & Sunderprasad X Langra & - \\
\hline $\mathbf{G}_{\mathbf{1}}$ & Bombai & & \\
\hline $\mathbf{G}_{\mathbf{2}}$ & Kalapadi & & \\
\hline $\mathbf{G}_{\mathbf{3}}$ & Alphonso & & \\
\hline $\mathbf{G}_{\mathbf{4}}$ & Fazli & & \\
\hline $\mathbf{G}_{\mathbf{5}}$ & Gulabkhas & & \\
\hline $\mathbf{G}_{\mathbf{6}}$ & Langra & & \\
\hline $\mathbf{G}_{\mathbf{7}}$ & Amrapali & & \\
\hline $\mathbf{G}_{\mathbf{8}}$ & Sunderprasad & & \\
\hline
\end{tabular}


Table.2 Plant morphological characters with observation

\begin{tabular}{|c|c|c|c|c|c|c|c|c|c|c|c|c|c|c|c|c|c|}
\hline \multirow[t]{2}{*}{ Traits } & \multirow{2}{*}{$\begin{array}{l}\text { Observation } \\
\text { recorded }\end{array}$} & \multicolumn{16}{|c|}{ Mango Hybrids with their parentage } \\
\hline & & H-1 & H-2 & H-3 & H-4 & H-5 & H-6 & H-7 & H-8 & G-1 & G-2 & G-3 & G-4 & G-5 & G-6 & G-7 & G-8 \\
\hline \multirow[t]{4}{*}{ Tree height } & Very Tall & - & - & $\checkmark$ & - & - & - & - & - & $\checkmark$ & - & - & $\checkmark$ & - & $\checkmark$ & - & - \\
\hline & Tall & - & $\checkmark$ & - & - & - & $\checkmark$ & $\checkmark$ & - & - & - & - & - & - & - & - & $\checkmark$ \\
\hline & Medium & $\checkmark$ & - & - & $\checkmark$ & - & - & - & $\checkmark$ & - & $\checkmark$ & $\checkmark$ & - & $\checkmark$ & - & - & - \\
\hline & Short & - & - & - & - & $\checkmark$ & - & - & - & - & - & - & - & - & - & $\checkmark$ & - \\
\hline \multirow[t]{3}{*}{ Tree shape } & Semicircular & $\checkmark$ & - & - & - & $\checkmark$ & $\checkmark$ & $\checkmark$ & - & - & - & $\checkmark$ & - & $\checkmark$ & - & - & - \\
\hline & Oblong & - & $\checkmark$ & - & - & - & - & - & $\checkmark$ & - & $\checkmark$ & - & $\checkmark$ & - & - & - & $\checkmark$ \\
\hline & $\begin{array}{l}\text { Broadly } \\
\text { pyramidal }\end{array}$ & - & - & $\checkmark$ & $\checkmark$ & - & - & - & - & $\checkmark$ & - & - & - & - & $\checkmark$ & $\checkmark$ & - \\
\hline \multirow{3}{*}{$\begin{array}{l}\text { Foliage } \\
\text { colour }\end{array}$} & Dark green & $\checkmark$ & $\checkmark$ & $\checkmark$ & $\checkmark$ & - & $\checkmark$ & $\checkmark$ & - & $\checkmark$ & - & $\checkmark$ & $\checkmark$ & - & $\checkmark$ & - & - \\
\hline & Green & - & - & - & - & $\checkmark$ & - & - & $\checkmark$ & - & - & - & - & $\checkmark$ & - & $\checkmark$ & - \\
\hline & Pale green & - & - & - & - & - & - & - & - & - & $\checkmark$ & - & - & - & - & - & $\checkmark$ \\
\hline \multirow{3}{*}{$\begin{array}{l}\text { Foliage } \\
\text { density }\end{array}$} & Dense & $\checkmark$ & $\checkmark$ & $\checkmark$ & $\checkmark$ & - & $\checkmark$ & - & - & - & - & $\checkmark$ & - & $\checkmark$ & - & $\checkmark$ & $\checkmark$ \\
\hline & Intermediate & - & - & - & - & $\checkmark$ & - & - & - & - & $\checkmark$ & - & $\checkmark$ & - & $\checkmark$ & - & - \\
\hline & Sparse & - & - & - & - & - & - & $\checkmark$ & $\checkmark$ & $\checkmark$ & - & - & - & - & - & - & - \\
\hline \multirow[t]{2}{*}{ Leaf shape } & Lanceolate & - & - & $\checkmark$ & $\checkmark$ & - & $\checkmark$ & $\checkmark$ & $\checkmark$ & $\checkmark$ & $\checkmark$ & - & $\checkmark$ & $\checkmark$ & $\checkmark$ & $\checkmark$ & $\checkmark$ \\
\hline & $\begin{array}{l}\text { Oblong } \\
\text { lanceolate }\end{array}$ & $\checkmark$ & $\checkmark$ & - & - & $\checkmark$ & - & - & - & - & - & $\checkmark$ & - & - & - & - & - \\
\hline \multirow[t]{3}{*}{ Fruit colour } & Yellow orange & - & - & - & - & - & - & - & - & - & - & $\checkmark$ & - & - & - & - & - \\
\hline & Golden yellow & - & - & - & - & - & - & - & - & - & $\checkmark$ & - & - & - & $\checkmark$ & - & - \\
\hline & Greenish yellow & $\checkmark$ & $\checkmark$ & $\checkmark$ & $\checkmark$ & $\checkmark$ & $\checkmark$ & $\checkmark$ & $\checkmark$ & $\checkmark$ & - & - & $\checkmark$ & $\checkmark$ & - & $\checkmark$ & $\checkmark$ \\
\hline \multirow{2}{*}{$\begin{array}{l}\text { Fruit } \\
\text { attractiveness }\end{array}$} & Attractive & - & - & - & - & - & - & - & - & - & $\checkmark$ & $\checkmark$ & $\checkmark$ & - & $\checkmark$ & - & $\checkmark$ \\
\hline & Non attractive & $\checkmark$ & $\checkmark$ & $\checkmark$ & $\checkmark$ & $\checkmark$ & $\checkmark$ & $\checkmark$ & $\checkmark$ & $\checkmark$ & - & - & - & $\checkmark$ & - & $\checkmark$ & - \\
\hline
\end{tabular}

Abbreviations: H-1 (Mahmood Bahar); H-2 (Prabhashankar); H-3 (Alfazli); H-4 (Sabri); H-5 (Jawahar); H-6 (Sunderlangra); H-7 (Hybrid 140); H-8 (Hybrid 601); G-1 (Bombai); G-2 (Kalapadi); G-3 (Alphonso); G-4 (Fazli); G-5 (Gulabkhas); G-6 (Langra); G-7 (Amrapali); G-8 (Sunderprasad) 
Table.3 Leaf and fruit quantitative traits of mango hybrids and their parents

\begin{tabular}{|l|c|c|c|c|c|c|}
\hline $\begin{array}{l}\text { Mango hybrids and } \\
\text { their parents }\end{array}$ & $\begin{array}{c}\text { Leaf } \\
\text { length } \\
(\mathbf{c m})\end{array}$ & $\begin{array}{c}\text { Leaf } \\
\text { width } \\
(\mathbf{c m})\end{array}$ & $\begin{array}{c}\text { Leaf area } \\
\left(\mathbf{c m}^{\mathbf{2}}\right)\end{array}$ & $\begin{array}{c}\text { Fruit weight } \\
(\mathbf{g})\end{array}$ & $\begin{array}{c}\text { Fruit length } \\
(\mathbf{m m})\end{array}$ & $\begin{array}{c}\text { Fruit width } \\
(\mathbf{m m})\end{array}$ \\
\hline Mahmood bahar & 16.96 & 5.06 & 51.15 & 246.60 & 91.12 & 72.96 \\
\hline Prabhashankar & 20.80 & 4.93 & 62.08 & 339.33 & 108.90 & 78.84 \\
\hline Alfazli & 29.26 & 7.56 & 145.36 & 458.10 & 129.64 & 80.56 \\
\hline Sabri & 21.30 & 5.86 & 65.22 & 135.55 & 77.32 & 56.65 \\
\hline Jawahar & 19.43 & 4.83 & 60.40 & 240.00 & 103.58 & 68.91 \\
\hline Sunderlangra & 24.66 & 6.40 & 74.18 & 266.60 & 93.97 & 71.77 \\
\hline Hybrid 140 & 22.70 & 5.73 & 66.49 & 225.20 & 92.20 & 63.28 \\
\hline Hybrid 60 -1 & 21.03 & 6.46 & 67.25 & 402.60 & 124.66 & 87.46 \\
\hline Bombai & 21.13 & 6.10 & 66.63 & 253.66 & 85.90 & 66.46 \\
\hline kalapadi & 22.36 & 4.20 & 65.64 & 252.86 & 89.53 & 71.28 \\
\hline Alphonso & 17.56 & 4.46 & 54.47 & 203.30 & 80.23 & 63.13 \\
\hline Fazli & 28.20 & 8.73 & 127.08 & 490.66 & 136.44 & 88.57 \\
\hline Gulabkhas & 16.43 & 4.03 & 50.63 & 202.00 & 86.70 & 60.64 \\
\hline Langra & 23.53 & 5.50 & 54.83 & 230.66 & 92.50 & 66.50 \\
\hline Amrapalli & 21.06 & 5.06 & 64.76 & 229.33 & 111.10 & 71.31 \\
\hline Sunderprasad & 18.46 & 5.16 & 56.31 & 196.80 & 96.00 & 70.50 \\
\hline SE diff. Mean & $\mathbf{2 . 2 4}$ & $\mathbf{0 . 6 9}$ & $\mathbf{1 . 0 4}$ & $\mathbf{2 9 . 3 2}$ & $\mathbf{4 . 9 6}$ & $\mathbf{2 . 7 9}$ \\
\hline CD at 5 \% & $\mathbf{4 . 6 0}$ & $\mathbf{1 . 4 2}$ & $\mathbf{2 . 1 3}$ & $\mathbf{6 0 . 1 7}$ & $\mathbf{1 0 . 1 8}$ & $\mathbf{5 . 7 4}$ \\
\hline CV \% & $\mathbf{1 2 . 7 3}$ & $\mathbf{1 5 . 0 9}$ & $\mathbf{1 . 8 0}$ & $\mathbf{1 2 . 2 0}$ & $\mathbf{5 . 3 2}$ & $\mathbf{4 . 7 7}$ \\
\hline
\end{tabular}

Table.4 Fruit quality content of mango hybrids and their parents

\begin{tabular}{|l|c|c|c|}
\hline $\begin{array}{l}\text { Mango hybrids and } \\
\text { their parents }\end{array}$ & TSS $\left({ }^{\mathbf{0}}\right.$ Brix $)$ & Acidity (\%) & TSS/ Acidity \\
\hline Mahmood bahar & 20.50 & 0.26 & 78.80 \\
\hline Prabhashankar & 22.20 & 0.39 & 56.92 \\
\hline Alfazli & 17.80 & 0.27 & 65.92 \\
\hline Sabri & 21.26 & 0.31 & 68.58 \\
\hline Jawahar & 19.90 & 0.25 & 79.60 \\
\hline Sunderlangra & 19.43 & 0.21 & 92.52 \\
\hline Hybrid 140 & 17.30 & 0.30 & 57.66 \\
\hline Hybrid 60 -1 & 22.33 & 0.15 & 135.55 \\
\hline Bombai & 22.03 & 0.20 & 110.15 \\
\hline kalapadi & 19.23 & 0.30 & 64.10 \\
\hline Alphonso & 19.50 & 0.33 & 59.33 \\
\hline Fazli & 17.00 & 0.31 & 54.83 \\
\hline Gulabkhas & 22.30 & 0.13 & 171.05 \\
\hline Langra> & 20.10 & 0.21 & 95.57 \\
\hline Amrapalli & 22.60 & 0.13 & 173.33 \\
\hline Sunderprasad & 18.59 & 0.20 & 92.95 \\
\hline SE diff. Mean & $\mathbf{0 . 6 2}$ & $\mathbf{0 . 0 1 9}$ & $\mathbf{6 0 . 3 0}$ \\
\hline CD at 5 \% & $\mathbf{1 . 2 8}$ & $\mathbf{0 . 0 3 8}$ & $\mathbf{1 5 . 2 0}$ \\
\hline CV \% & $\mathbf{3 . 9 5}$ & $\mathbf{7 . 6 6}$ & $\mathbf{5 . 0 2}$ \\
\hline
\end{tabular}


Fig.1 Sixteen mango hybrids with their parentage for morphological and biochemical analysis

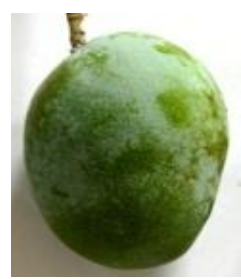

Mahmood

Bahar

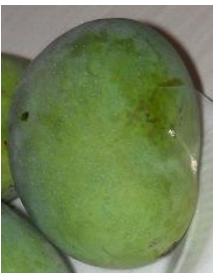

Alphonso

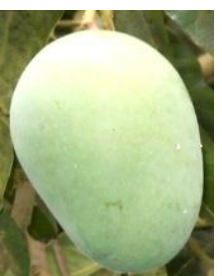

Hybrid 140

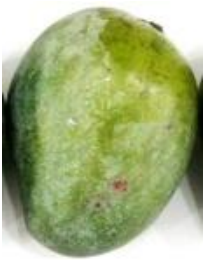

Prabha

Shankar

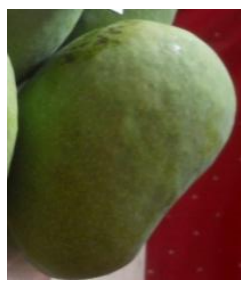

Fazli

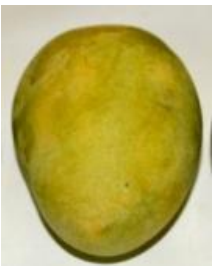

Hybrid 60-1

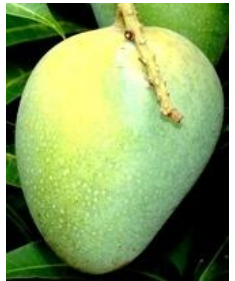

Bombai

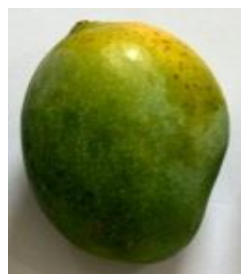

Jawahar

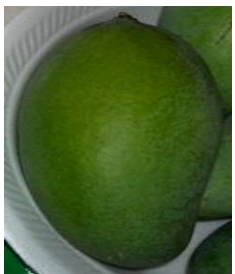

Amrapali

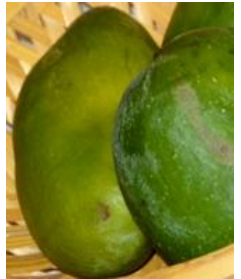

Kalapadi

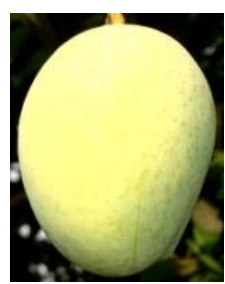

Sunderlangra

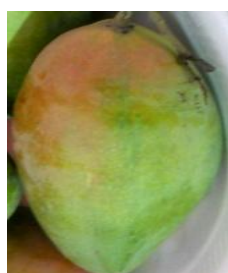

Sunderprasad

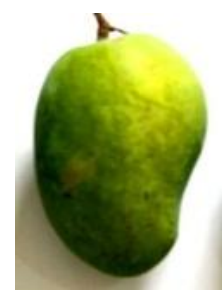

Alfazli

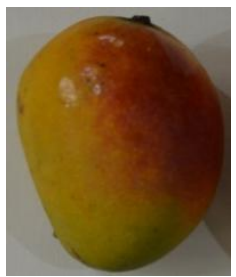

Gulabkhas

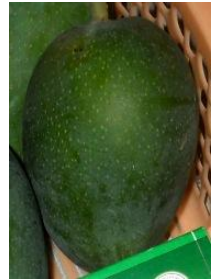

Sabri

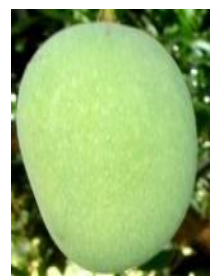

Langra

Fig.2 Chlorophyll and beta carotene content of leaf for biochemical analysis

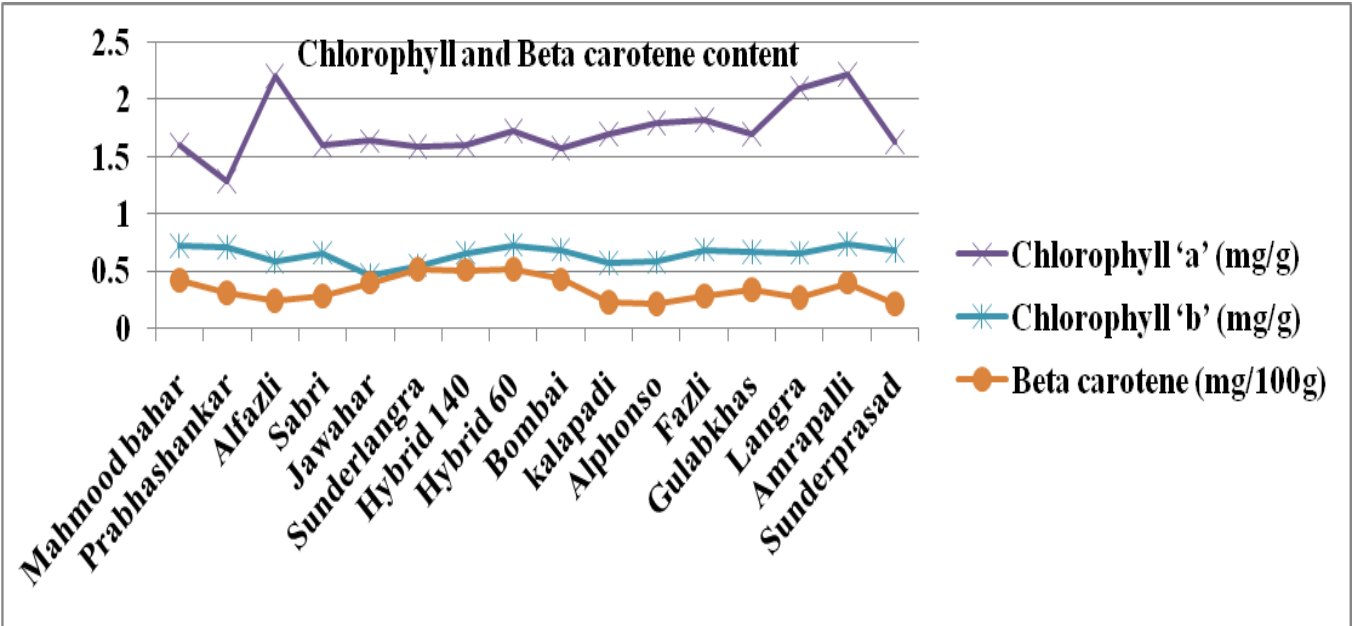

The data with respect to chlorophyll $a$ and $b$ content and beta carotene of mango leaf owing to different mango hybrid and their parentage were estimated and expressed as $\mathrm{mg} / \mathrm{g}$ and $\mathrm{mg} / 100 \mathrm{~g}$ respectively. The data so obtained were illustrated graphically in Figure 2. A careful scrutiny of data reveals that there was a significant variation for chlorophyll a 
and $\mathrm{b}$ and beta carotene content of leaf. The maximum Chlorophyll a $(2.22 \mathrm{mg} / \mathrm{g})$ and $\mathrm{b}$ $(0.747 \mathrm{mg} / \mathrm{g})$ was found in Amrapali which was significantly followed by Alfazli (2.20 $\mathrm{mg} / \mathrm{g})$. The lowest chlorophyll a $(1.29 \mathrm{mg} / \mathrm{g})$ was estimated in Prabha Shankar and $b$ in Jawahar $(0.463 \mathrm{mg} / \mathrm{g})$. The maximum value $(0.538 \mathrm{mg} / 100 \mathrm{~g})$ of beta carotene was recorded in Sunder Langra and Hybrid 60-1 and lowest value $(0.213 \mathrm{mg} / 100 \mathrm{~g})$ in Alphonso.

In mango, the pigment content is influenced by different seasons, cultivars, growth and maturity stages of leaves (Pandey and Tyagi, 1999; Nii et al., 1995). The cultivars with high chlorophyll content can produce higher biomass and increase photosynthesis (Hassan et al., 2009). Whereas, Chen et al., (2010) reported that there was no relationship between total chlorophyll and photosynthesis in matured leaves of mango cultivars. The variation of $\beta$-carotene content between the different varieties was also revealed in this study. The $\beta$-carotene content of mango is related to several factors including the genetic, the stage of maturity, climate or geographic site production and cultivation techniques used by Muoki et al., (2009) and Nestel et al., (2006).

On the basis of fruit character among the hybrids of mango, Hybrid 60-1, Alfazli and Prabhashankar gives better result in fruit weight, fruit length and fruit width whereas among the parents Fazli gives better result. On the basis of fruit quality Hybrid 60-1 gives better result in terms of TSS, acidity and TSS/acidity ratio among the hybrids while Amrapali, Gulabkhas and Bombai gives better result among the parents. Amrapali also having highest chlorophyll $\mathrm{a}$ and $\mathrm{b}$ content in their leaves whereas beta carotene recorded maximum in Hybrid 60-1. Since the present experiment confirm that wide variation is present among different mango cultivars regarding morphological and biochemical characters, hence these morpho-chemical characters can be used as an efficient tool for proper identification of different cultivars well before the commencement of that cultivar to bearing stage, which will ultimately helps the mango breeders for shortening the improvement period.

\section{References}

Jha, S. K., Sethi, S., Srivatav, M., Dubey, A. K., Sharma, R. R., Samuel, D. V. K. and Singh, A.K., (2010), Firmness characteristics of mango hybrid under ambient storage. J. Food Eng., 97: 208-212.

Popenoe, W., (1927), Manual of tropical and subtropical fruits. McMillan, New York, USA.

Mukherjee, S. K. (1951), The origin of mango. Indian J. of Genetics., 2: 49.

De candolle, A., (1904), Origin of cultivated plants. Kegan Paul, Trench, London.

Anonymous, 2011, Indian horticulture database, 2011. NHB, Gurgaon, Haryana, India, pp. 2-93.

Poovarodom, S., Haruenkit, R., Vearasilp, S., Namiesnik, J., Cvikrová, M., Martinincová, O., Ezra, A., Suhaj, M., Ruamsuke, P., and Gorinstein, S., (2010), Comparative characterization of durian, mango and avocado. Food Sci. Technol., 45: 921-929.

Mian, I. H. and Nasir, M. A., (1989), New Sammar Bahisht Strains of mango. The Punjab Fruit J., 41: 50-51

Mukherjee, S. K., R. N. Singh, P. K. Majumder and Sharma, D. K., (1968), Present position regarding breeding of mango in India. Euphytica, 17: 462467.

Chadha, K. L. and Pal, R. N., (2004), Mango culture far and near. In: Ahmad, S. (ed.), Mangoes in Pakistan., pp: 150162. The Horticultural Foundation of 
Pakistan, Islamabad

Knight, R. J., (1993), Evaluating important fruit characters in mango germplasm. Fruit Var. J., 47: 25-31.

Campbell, C. W., (1995), Mangoes in the United States: A yearlong supply. Proc. Florida State Hortic. Soc., 107: 303-334.

International Plant Genetic Resources Institute (IPGRI). (2006), Descriptors of Mango (Mangifera indica L.). Rome, Italy. $44 \mathrm{pp}$.

A.O.A.C, (2000), Official Methods of Analysis, 17th ed. Association of Official Analytical Chemists, Gaithersburg, MD.

Kumari, P., Barman, K., Patel, V. B., Siddiqui, M. W. and Kole, B., (2015), Reducing postharvest pericarp browning and preserving health promoting compounds of litchi fruit by combination treatment of salicylic acid and chitosan. Sci Horti., 197: 555-563.

Barnes, J. D., Balaguer, L., Manrique, E., Elvira, S. and Davison, A. W., (1992), A reappraisal of the use of DMSO for the extraction and determination of chlorophylls-a and chlorophylls-b in lichens and higher-plants. Environ. Exp. Bot., 32: 85-100.

Ranganna, S. 2011. Handbook of analysis and quality control for fruit and vegetable products. Second edition.

Shivashankara, K. S. and Mathai, C. K., (2000), Inhibition of photosynthesis by flowering in mango (Mangifera indica L.). A study by gas exchange methods. Sci. Hortic., 83: 205-212.

Sharma, J. N., Josan, J. S., Thind, S. K. and Arora, P. K., (1999), Evaluation of mango cultivars for arid-irrigated region of Punjab. J. Appl. Hortic., 1: 103-104.

Reddy, N. N., Gangopadhyay, K. K., Singh, H. P., Rai, M. and Kumar, R., (2000),
Adaptability of mango cultivars under sub-humid Alfisols of Eastern India. $J$. Res. Birsa Agric. Univ., 12: 163-169.

Rymbai, H., Laxman, R. H., Dinesh, M. R., Johnsunoj, V. S., Ravishankar, K. V. And Jha, A. K., (2014), Diversity in leaf morphology and physiological characteristics among mango (Mangifera indica) cultivars popular in different agro-climatic regions of India. Sci. Hort., 176: 189-193.

Human, C. F., And S. Rheeder., (2004), Mango breeding: results and successes. Acta Hortic., 645: 331-335.

Lodh, S. B., Subramanyam, M. D. and Divakar, N. G., (1974), Physicochemical studies of some important mango verities. Indian J. Hort., 31(2): 160-161.

Iqbal, S. M., Uddin, M. S. and Shaku, M. A., (1995), Performance of exotic mango germplasm under Bangladesh conditions. In: Annual Report on Mango Improvement (1994-95), Regional Horticultural Research Station, Bangladesh Agricultural Research Institute, Nawabgonj. pp. 19.

Kumar, R. and Singh, S., (2005), Evaluation of mango genotypes for flowering, fruiting and fruit quality attributes. Orissa J. Hort., 33(1): 77-79.

Sengupta, S., Munsi, P. S. And Pujari, M. M., (2006), Studies on the performance and prospect of some promising mango hybrids in the Gangetic plains of Eastern Bihar. The Orissa J. Hort., 34 (2): 74-77.

Kumar, R., Kaushik, R. A. and Chharia, A. S., (1992), Effect of post-harvest treatments on the quality of mango during storage. Haryana J. Hort. Sci., 21: 46-55.

Pandey, S., and Tyagi, D. N., (1999), Changes in chlorophyll content and photosynthetic rate of four cultivars 
during reproductive stage. Biol. Plant., 42: 457-461.

Nii, N., Watanable, Y., Yamaguchi, K. and Nishimura, M. (1995), Changes of anatomical features, photosynthesis and ribulose biphosphate carboxylase oxigenase content in mango leaves. Ann.Bot., 76: 649-659.

Hassan, M. S., Khair, A., Haque, M. M., Azad, A. K. and Hamid, A., (2009), Genotypic variation in traditional rice varieties for chlorophyll content, SPAD value and nitrogen use efficiency. Bangladesh J. Agric. Res., 34: 505-515.

Chen, H. R., Chen, Y. Y., Gao, A. P., Ni, Z.
G., Deng, S. S., Zhu, M., Xie, D. H., Long, Y. Q. and Zhang, F. M., (2010), Study on relationship between chlorophyll, specific leaf weight and net photosynthetic rate of mango. Southwest China J. Agric. Sci., 23: 1848-1850.

Muoki, P. N., Makokha A. O., Onyango, C. A., (2009), Potential contribution of mangoes to reduction of vitamin A deficiency in Kenya. Ecol Food Nutr., 48: 482-498.

Nestel, P., Bouis, H. E., Meenakshi, J. V., (2006), Biofortification of Staple Food Crops. J. Nutr., 136: 1064-1067.

\section{How to cite this article:}

Syed Razaul Islam, Kumari Karuna, Abha Kumari, Abhay Mankar and Feza Ahmad. 2019. Varietal Characterization and Quality Assessment of Mango Hybrid and their Parents through Morphological and Biochemical Markers. Int.J.Curr.Microbiol.App.Sci. 8(04): 697-706. doi: https://doi.org/10.20546/ijcmas.2019.804.075 